\title{
SPECIALIZUOTOS VAISTININKO TEIKIAMOS PASLAUGOS ASTMA SERGANTIEMS PACIENTAMS POREIKIO ANALIZE LIETUVOJE
}

\author{
Arturas Nastaravičius, Kristina Ramanauskienė \\ Lietuvos sveikatos mokslu universiteto Farmacijos fakultetas, Klinikinès farmacijos katedra
}

Raktažodžiai: bronchų astma, vaistininko konsultacija, vertinimas, inhaliavimo technika.
Santrauka
Lietuvoje astma sergančių pacientų skaičius nuose- kliai didejja. $2017 \mathrm{~m}$. duomenimis, astma sirgo dau- giau nei 121300 pacientų, iš kurių daugiau nei 43500 suaugę asmenys.
Tyrimo tikslas - ivertinti, ar vaistininko teikiama specializuota išplèstinè konsultacija apie paskirtus vaistus astmai gydyti gali turèti ịtakos pacientų li- gos kontrolei.
Metodai - grindžiamosios teorijos pagrindu atliktas kokybinis tyrimas bei kiekybinis tyrimas. Naudo- tas dedukcijos metodas buvo paremtas astmos val- dymo ir vaistų vaidmens publikacijomis. Duomenu statistiniam apdorojimui buvo naudojama Smirnovo- Kolmogorovo (Smirnov-Kolmagorov) $\chi^{2}$ kvadrato, Stjudento t bei Stjudento t (Student) porinių imčiu kriterijai, Mano Vitney (Mann Whitney) kriterijus bei Spirmeno (Spearman) koreliacijos koeficientas Rezultatai - kokybinio tyrimo metu buvo nustatyta, kad farmacijos specialistai astma sergantiems pa- cientams turi pateikti informaciją apie vartojamų vaistų profili ir veikimą, gydymosi rěžimo nesilai- kymo pasekmes, inhaliatoriaus technikos ypatumus, ligos simptomus, nekontroliuojamų simptomų įtaką sveikatai, astmos kontrolès lygmenis. Nustatyta, kad prieš atlekant tyrimą iš 244 tiriamujų visiškai už- baigusių paslaugos ciklą 73,8 proc. nepakankamai kontroliavo ligos simptomus. Po intervencijos nepa- kankamai kontroliuojančiu ligos simptomus suma- žejo iki 54,92\%. Daugiausia inhaliavimo klaidų dare tiriamieji, vartojantys Aerolizer bei Aerosol inhaler inhaliatorius. Mažiausiai Easyhaler, Turbohaler bei Accuhaler. Po atliktos konsultacijos, vidutinis klaidu skaičius sumažèjo nuo 2,284 iki 1,110 (kai p<0,05). Išvada - tiriamosios grupès statistiškai reikšmingas

ligos simptomų kontroliavimo didejjimas bei daromų inhaliavimo klaidų skaičiaus sumažèjimas įrodo, kad astma sergančių pacientų priežiūros grandinèje, greta gydytojo ir slaugytojos integruojant farmacijos specialistą, galima pasiekti racionalaus vaistų vartojimo bei geresnių ligos simptomų kontroliavimo.

\section{Ivadas}

Bronchine astma yra viena iš dažniausiai pasitaikančių lètinių ligų vaikų ir suaugusių populiacijoje [1], kuri turi reikšmingą ịtaką žmogaus gyvenimo kokybei ir darbingumui. Lietuvoje astmos paplitimas tarp gyventojų yra vienas didžiausių centrinejje Europoje ir astmos gydymas patenka i 10 pagrindinių priežasčių, dèl kurių pacientai kreipiasi ị šeimos gydytojus [2]. Parenkant vaistus astmai gydyti, būtina atsižvelgti į paciento gebejimą tinkamai ịkvèpti vaistus po apmokymo bei nusiteikimą, susijusị su paskirto gydymo režimo priimtinumu [3].

Astmos eiga dažniausiai kontroliuojama vartojant vaistus, tačiau dèl blogai kontroliuojamu astmos simptomu kasmet pasaulyje miršta apie 250000 pacientu [4]. Atsižvelgiant ị sergamumo statistiką, bandoma sukurti ịvairius paslaugų modelius astmos kontrolei užtikrinti, jie apima pacientų apmokymą naudoti vaistus, savo būklès stebejjimą, iškvépimo-įkvėpimo stiprumą, nekontroliuojamų simptomų sekimą ir registravimą [5].

Kitų mokslininkų tyrimų duomenimis, ị sveikatos priežiūros stebėsenos grandinę integravus farmacijos specialistą, galima pasiekti teigiamų astmos kontrolès rezultatų [6-9]. Dažniausiai astmos mokymosi programas vykdo gydytojai arba slaugytojai [10], tačiau tarptautinès rekomendacijos nurodo, kad i pacientų mokymosi procesą būtina įtraukti kitus sveikatos priežiūros specialistus [11]. Nepaisant didelio pacientu skatinimo išmokti kontroliuoti ligos simptomus pasauliniu mastu, asmenini astmos kontrolès planą turi tik trečdalis pacientų [12,13]. Pagrindinès klaidos, kurias daro astma sergantys pacientai, susijusios su netinkamu vaisto prietaiso naudojimu [14]. Remiantis kitų mokslininkų atlik- 
tais tyrimais, visame pasaulyje vaistininkai dalyvauja sveikatos ugdymo ir ligu prevencijos programose, susijusiose su vartojimu arba vaistų išdavimu [15].

Lietuvoje vaistininkas yra sveikatinimo specialistas, tačiau ne sveikatos priežiūros specialistas, kaip tai nurodoma Europos Sajungos direktyvoje [16]. Šis teisinis skirtumas užkerta kelią vaistininkui Lietuvoje užsiimti intervencinèmis programomis su pacientais ar kitaip priimti sprendimus, susijusius su pacientu gydymu vaistais. Vaistininkai gali prisidèti prie pacientų edukacijos, taip pagerinant ligos kontrolę bei gyvenimo kokybę [7], taip pat yra vienas iš dažniausiai lankomų ir lengviausiai prieinamų sveikatos specialistų sistemoje. Iprastai gyventojams vaistinejje suteikiama informacija apie vaisto dozę, vartojimo dažnumą bei vartojimo laiką. Dažniausiu atveju pacientai, sergantys astma, naudoja bent vieną vaistą, kuris yra inhaliatoriuje. Pacientams skiriama dozuoti aerozoliniai (DAI), sroviniai purkštuvai bei milteliniai inhaliatoriai [17], šiuo metu Lietuvoje yra prieinama 12 skirtingų inhaliatorių rūšių . Atsižvelgiant ị tai, kad Lietuvoje yra daugiau kaip 121300 astma sergančių pacientų [19], o daugeliu atvejų astma yra gydoma inhaliuojamais preparatais, kurių naudojimo technikos skiriasi, svarbu didinti farmacijos specialistų teikiamas paslaugas, skirtas užtikrinti astmos kontrolę [19]. Mes manome, kad išplèstinè vaistininko konsultacija astmos gydymo procese apie inhaliatorių naudojimą bei ligos kontrolę gali turèti teigiamą itaką siekiant efektyvaus asmos gydymo ir kontroliavimo vaistais. Galima numatyti, kad astmos gydymo procese dalyvaujant sveikatos priežiūros specialistams ir vaistininkui būtų sudarytos tinkamos sąlygos kontroliuoti astmą, kadangi tinkama vaisto ịkvejpimo technika, teisingas vaistų vartojimas gali pagerinti/užtikrinti astmos kontrolę, sumažinti ligos gydymo kaštus.

Šio tyrimo tikslas - ivvertinti, ar vaistininko teikiama specializuota išplèstinè konsultacija apie paskirtus vaistus astmai gydyti gali tureti įtakos pacientų ligos kontrolei. Kitas tikslas buvo išsiaiškinti, ar daromų klaidų skaičius inhaliavimo technikoje turi įtakos ligos kontrolei.

\section{Metodai}

Tyrimo metodika buvo pasirinkta grindžiant paralelinio kontroliuojamo tyrimo dizainu, kuris buvo atliktas nuo 2017 $\mathrm{m}$. balandžio mèn. iki $2018 \mathrm{~m}$. sausio mèn. imtinai. Visi tyrimo metodai buvo iqvertinti ir patvirtinti Lietuvos bioetikos komiteto (Leidimo nr. 14-14-06). Tyrimas buvo atliktas 21 vaistineje, išsidèsčiusiose visuose Lietuvos regionuose, priklausančiose vienam iš Lietuvoje veikiančių vaistinių tinklų. Vaistinès buvo atrinktos atsižvelgiant ị pacientų, sergančių bronchine astma, turimą srautą bei lokaciją greta gydymo istaigų. 25 vaistininkai dalyvavo tyrime ir buvo apmokyti 1-os dienos kursuose gydytojų pulmonologų bei pagrindinių tyrèjų apie vaistų, skirtų astmai gydyti, veikimą, naudojimą, gydymosi režimo laikymąsi. Taip pat buvo pristatytas ir išanalizuotas tyrimo protokolo bei kitų tyrimo dokumentų formų rengimas, siekiant standartizuoto duomenų pildymo.

Pagrindiniais rezultatais buvo laikoma astmos kontrolès pokytis, kuris buvo įvertinamas pagal pakartotinai atliekamus 2 astmos kontrolès testus (ACT), kuriuos užpildydavo pats pacientas, o vaistininkas ịvertindavo būklę pagal nustatytą metodiką 25 balų skaičiavimo skaleje.

Antriniai rezultatai buvo laikomi inhaliatoriaus technikos ir vaistų vartojimo duomenys. Vaistininkas inhaliatorių naudojimo techniką vertindavo skirdamas 2-jų inhaliatorių tipus: dozuotų aerozolinių inhaliatorių (MDI) ir miltelinių inhaliatorių (DPI) metodikomis [20]. Respondentai turejjo pademonstruoti vaistininkui jiems iprastą inhaliatoriaus naudojimo techniką naudojant atitinkamos rūšies placebo inhaliatorių, o vaistininkas registruodavo paciento klaidas pagal numatytą naudojimo techniką [21]. Pacientai, kurie ivykdydavo visus privalomus naudojimosi technikos žingsnius, buvo laikomi kaip tinkamai naudojantys prietaisą.

1 etapas: kokybinis tyrimas. Pirmasis tyrimo etapas buvo paslaugos poreikio analize, atlikta naudojant pusiau struktūrizuotą interviu metodiką, sukurtą grindžiamosios teorijos pagrindu su 8 visuomenès vaistininkais. Atlikus literatūros analizę [5-13] sukurtas pusiau struktūrizuotas interviu. Naudotas dedukcijos metodas buvo paremtas astmos valdymo ir vaistų vaidmens (GINA - Global Initiative for Asthma or the Asthma Management Handbook) publikacijomis. Kokybinio tyrimo respondentai buvo parinkti ir apklausti darbo vietose - vaistinèse, kurios turi pastovų asmta sergančių pacientų srautą. Interviu buvo vykdomas žodžiu, o turinio analizė buvo atlikta identifikuojant pasikartojančiai minimus paslaugos segmentus. Duomenys buvo priskirti kategorijoms ir subkategorijoms. Pagrindiniai paslaugos segmentai buvo sukurti pasinaudojant šių subkategorijų ir kategorijų grupavimu į temas.

Pusiau struktūrizuoto interviu klausimai buvo suskirstyti i 2 dalis: 1) astmos valdymo paslaugos koncepcija; 2) vaistininko gebejimas teikti farmacinę paslaugą astma sergantiems pacientams.

2 etapas: kiekybinis tyrimas. Antruoju tyrimo etapu buvo vertinamas pagal kokybinio tyrimo rezultatus grịstas paslaugos modelis. Kokybiniame tyrime dalyvavę vaistininkai ịvardijo, kad Lietuvos sveikatos priežiūros sistemoje nèra specialisto, kuris nuolat stebètų ir vertintų pacientų astmos kontrolę ir reguliariai pacientus mokytų tinkamai vartoti paskirtus gydytojo vaistus, iskaitant ir prietaisus, skirtus vaistams vartoti.

Farmacinés paslaugos astma sergančiam pacientui 
modelis. Paslaugos ciklą sudarè ne mažiau nei du vizitai vaistinèje per šešis mènesius, bet ne anksčiau nei po vieno mènesio. Buvo naudojamos dvi astmos kontrolès priemonès: 1) astmos kontrolès testas (ACT) ir 2) sturktūrizuotas klausimynas apie paciento ligos būklę (parengtas pagal kokybinio tyrimo rezultatus (1 lentelè), išrašytus vaistinius preparatus, jų naudojimą bei inhaliavimo techniką. Astmos kontrolès testas yra validuotas kituose tyrimuose [5-13,20].

Vertinant turini, paslauga turèjo du elementus: paciento mokymo etapą (vaistininko informacija apie astmą, vaistus, vaistų nevartojimo riziką, ligos kontrolès poveiki fiziologiniams procesams) ir paslaugos elementą, kur buvo interpretuojami paciento duomenys, konkretaus paciento vaisto vartojimo ịpročiai, patikrinama ligos kontrole, inhaliavimo technika, naudojamų vaistų profilio ypatumai su gyvenimo būdu.

Tiriamieji turejo atvykti ị vaistinę bent du kartus. Vizitai savo turiniu tarpusavy skyrèsi. Pirmojo ir antrojo vizitu turinys parodytas 1 lenteleje.

Siekiant sužinoti didžiausią įtaką turinčius ligos kontrolès veiksnius, rezultatai buvo ịvertinti pagal gydymo planą ir nustatant ligos kontrolę priklausomai nuo inhaliacinių metodų klaidų skaičiaus.

Pacientu atranka. Tyrime galèjo dalyvauti pacientai vyresni kaip 18 metų ir sergantys praeityje diagnozuota

1 lentelè. Astmos konsultacijos struktūra I ir II vizito metu.

\begin{tabular}{|l|c|c|}
\hline Temos & Vizitas 1 & Vizitas 2 \\
\hline 1. Astmos kontrolès testas & $\checkmark$ & $\checkmark$ \\
2. Inhaliavimo technikos patikra & $\checkmark$ & $\checkmark$ \\
3. Informacija apie vaistų profilius & $\checkmark$ & $\checkmark$ \\
4. Neteisingo vaistų vartojimo rizikos & $\checkmark$ & $\checkmark$ \\
$\begin{array}{l}\text { 5. Informacija apie astmos ligą } \\
\text { 6. Kontroliuojamos astmos įtaka gyve- } \\
\text { nimo būdui }\end{array}$ & $\checkmark$ & \\
\hline
\end{tabular}

2 lentelè. Tiriamosios ir kontrolinès grupès palyginimas.

\begin{tabular}{|l|c|l|}
\hline & $\begin{array}{l}\text { Ti i i a m o j i } \\
\text { grupé }\end{array}$ & $\begin{array}{l}\text { Kontrolinè } \\
\text { grupé }\end{array}$ \\
\hline Imtis & 328 & 108 \\
\hline Neužbaigé paslaugos ciklo & $84(25,61 \%)$ & $17(15,75 \%)$ \\
\hline Užbaigę paslaugos ciklą & $244(74,39 \%)$ & $91(84,25 \%)$ \\
\hline Moterys & $144(59,00 \%)$ & $50(54,94 \%)$ \\
\hline Vyrai & $100(41,00 \%)$ & $41(45,06 \%)$ \\
\hline $\begin{array}{l}\text { Kontroliuojantys astmą (prieš } \\
\text { paslaugą) }\end{array}$ & $64(26,2 \%)$ & $23(25,27 \%)$ \\
\hline Turintys astmos kontrolès planą & $83(34,01 \%)$ & $32(35,16 \%)$ \\
\hline $\begin{array}{l}\text { Teisingai vartojantys paskirtus } \\
\text { vaistus }\end{array}$ & $75(30,73 \%)$ & $33(36,20 \%)$ \\
\hline
\end{tabular}

bronchine astma bei vartojantys gydytojo paskyrimu vaistus astmai gydyti. Taip pat atitiko vieną ar daugiau iš kriterijų: 1) naudojo vieną ar daugiau gydytojo paskirtų ikvejpiamųų vaistu astmai gydyti, 2) patirdavo nepakankamai kontroliuojamos astmos simptomus bent kartą per savaitę, 3) per paskutinius šešis mènesius nebuvo gydytojo pulmonologo konsultacijos. Tyrimo imtis buvo sudaryta atsižvelgiant $i$ 95\% pasikliovimo lygmenị ir 5\% standartinị nuokrypị.

Kontroline grupè. Siekiant išsamiai palyginti gautus rezultatus tyrime dalyvavo ir kontrolinè grupé, kurią sudarè 108 pacientai, iš kurių 91 ịvykdè pilną paslaugos ciklą. Pacientai ị kontrolinę grupę buvo atrinkti pagal tokius pat kriterijus kaip ir ị tiriamają. Kontrolinės grupès tiriamieji turèjo ivvykdyti du vizitus vaistineje, užpildyti AKT bei pademonstruoti vaistininkui savo inhaliavimo techniką, tačiau vaistininkas nevykdè konsultacijos. Tokiu metodu gauti rezultatai vèliau leido palyginti skirtumą tarp intervencinès grupès ligos kontrolès pokyčio su kontrolinès grupès pokyčiu.

Duomenu analizé. Surinkti tyrimo duomenys buvo konvertuoti ị skaitmeninį SPSS Windows 8.0 formatą ir buvo konfidencialiai saugomi juos užkoduojant ir nuasmeninant. Visi rezultatų kintamieji normalumo testai buvo atlikti su Smirnovo-Kolmogorovo testu. Priklausomybei tarp dvieju kintamujų nustatyti taikomas $\chi^{2}$ kvadrato kriterijus, vidurkiu palyginimui buvo naudojamas Stjudento t bei Stjudento $t$ porinių imčiu kriterijai, papildomai $p$ reikšmès validumui patikrinti buvo taikytas neparametrinis Mano Vitney kriterijus. Statistiniam ryšiui tarp kintamujų nustatyti taikomas neparametrinis Spirmeno (Spearman) koreliacijos koeficientas.

\section{Rezultatai}

Kokybinio tyrimo rezultatai. Kokybinio tyrimo duomenu analizè, naudojant pusiau struktūrizuotą interviu, nustaté vaistininko teikiamos paslaugos astma sergantiems pacientams turinio kategorijas: 1) informacija apie vartojamu vaistų profilį ir veikimą; 2) gydymosi rèžimo nesilaikymo pasekmes; 3) inhaliatoriaus technikos peržiūra ir korekcija; 4) informacija apie ligos simptomus; 5) nekontroliuojamu astmos simptomų įtaka sveikatos būklei; 6) astmos simptomų kontrolès lygmenys.

Kokybinio tyrimo rezultatai parodè vaistininkų galimybes teikti klinikinę paslaugą, skirtą astma sergantiems pacientams. Buvo ịvardyti trukdžiai sklandžiai teikti paslaugą: 1) žinių trūkumas; 2) ribotas laikas vaistinejje; 3 ) tarpprofesinio bendradarbiavimo įrankio nebuvimas; 4) pacientu informuotumas apie paslaugas. Atsižvelgiant ị kokybinio tyrimo rezultatus buvo atlikti veiksmai siekiant sklandžiai igyvendinti kiekybinio tyrimo metodiką.

Astmos kontrole tiriamuju grupëje. Tyrimas buvo vykdytas 21 Lietuvos vaistineje. Vaistininko astmos paslauga 
pasinaudojo 436 pacientai, iš kurių 108 dalyvavo kontrolinėje grupejje (pilną paslaugos ciklą ịvykdè 91 pacientas $(84,26 \%)$ ). Kontrolinès ir tiriamosios grupès demografiniai kriterijai buvo vienodi. Tiriamają grupę sudare 328 pacientai, iš jų pilną paslaugos ciklą, 2 vizitus vaistineje, ịvykdè 244 astma sergantys pacientai (2 lentelè). 84 pacientai įvykdè pirmają paslaugos dalį, tačiau neatvyko 2 vizito ị vaistinę. Tyrime buvo analizuojami duomenys tik tų asmenų, kurie įvykdè pilną paslaugos ciklą. Vidutinis tiriamujų imties amžius buvo 60,42 metų.

Tiriamujų grupejje prieš teikiant paslaugą visiškai ar pakankamai ligą kontroliavo 64 pacientai, t.y. 26,2 proc. tiriamosios grupès imties, o nepakankamai kontroliavo 180 tiriamujų, atitinkamai 73,8 proc. tiriamosios imties. Statistiškai reikšmingos priklausomybès tarp lyties ir ligos kontrolès nebuvo nustatyta $\left(\chi^{2}=0,132 ; \mathrm{p}>0.05\right)$.

Vidutinis pakankamai ligos simptomus kontroliuojančiu pacientų amžius buvo 60,35 metų, o tai mažai skiriasi nuo nustatyto ligos nekontroliuojančių pacientų amžiaus 60,44 metų. Naudojant Spirmeno koreliacijos koeficientą, statistiškai reikšmingos koreliacijos tarp amžiaus ir ligos kontrolès bei daromų klaidụ nebuvo rasta.

Vertinant ligos kontrolès rezultatus, patiektus 1 paveiksle, po paslaugos suteikimo tiriamoje grupeje nustatyta, kad ligą pa-

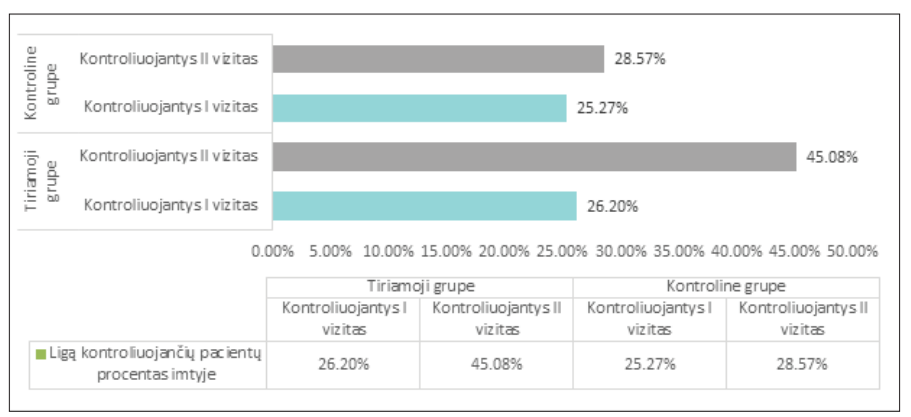

1 pav. Ligos kontrolès palyginimas tarp tiriamosios ir kontrolinès grupès prieš ir po paslaugos suteikimo.

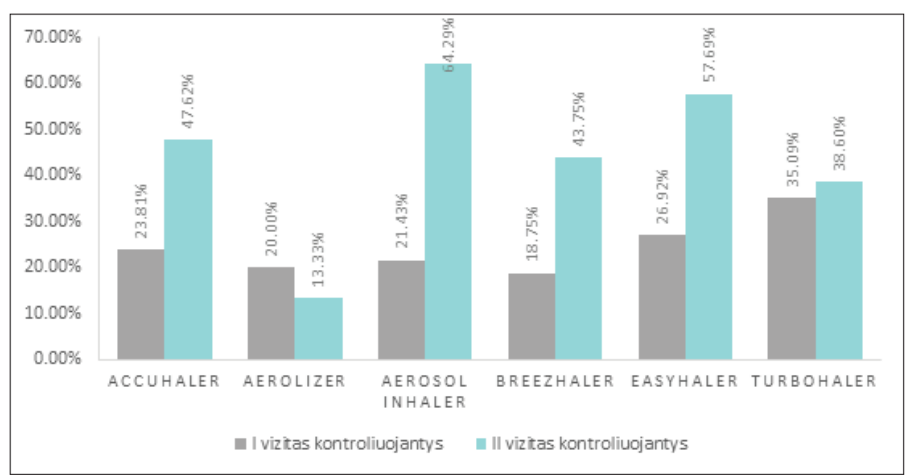

2 pav. Skirtingus inhaliatorius vartojančių pacientų ligos kontrolès palyginimas prieš ir po paslaugos. kankamai kontroliavo $(\mathrm{AKT}>19) 110$ pacientų $(45,08$ proc.), o nekontroliavo 134 pacientai (54,9 proc.). Naudojant $\chi^{2}$ kriterijų buvo nustatyta, kad 6 pacientai iš kontroliuojančiujų grupès tapo nepakankamai kontroliuojantys simptomus, o 58 pacientai nekapankamai kontroliavę simptomus pradejo pakankamai kontroliuoti ligą. Nebuvo nustatyta statistiškai reikšmingos priklausomybès tarp ligos kontrolès pokyčio ir lyties.

Taip pat naudojant porinių imčių Stjudento t testą buvo patikrinti AKT vidurkiai tiriamojoje imtyje ir gautas statistiškai reikšmingas vidurkio pokytis lyginant 1 vizito AKT rezultatus su 2 vizito AKT rezultatais. Pirmojo vizito AKT vidurkis buvo 15,893, tuo tarpu antrojo vizito AKT rezultatas buvo lygus 18,270 balo $(\mathrm{p}<0,05)$.

Astmos kontrole pagal naudojama inhaliatoriaus tipa. Visi tiriamieji naudojo bent vieną gydytojo skirtą astmai gydyti preparatą, patalpintą inhaliatoriuje. Šeši inhaliatorių tipai buvo nauojami pakankamai dažnai, kad būtų galima atlikti statistiškai reikšmingų skirtumų analizę $(\mathrm{p}<0,05)$. Tyrimų rezultatai pateikiami 2 paveiksle.

Rezultatai parode, kad daugiausia iš nekontroliuojančių simptomų grupès ị kontroliuojančius simptomus grupę perejo Aerosol inhaler (MDI), Easyhaler (DPI) bei Accuhaler (DPI) naudotojai. Aerosol inhaler (MDI), kaip pagrindinis vaistas skiriamas dar neprogresavus astmos ligai, todèl šių pacientų pagerèjimą lèmè ne tik teisinga technika ir gyvenimo būdo korekcija, bet ir lengvesnè ligos forma.

Vertinant pagal neteisingą inhaliavimo techniką, daugiausia klaidų pacientai darè su Aerolizer (DPI) bei Aerosol Inhaler (MDI) aparatais. Mažiausiai - su Easyhaler (DPI), Turbohaler (DPI), Accuhaler (DPI) inhaliatoriais.

Inhaliavimo klaidu itaka astmos kontrolei. Inhaliavimo technikos patikra leido palyginti pacientų inhaliavimo technikos itaką ligos kontrolei. Naudojant Stjudento t kriterijų nustatyta, kad egzistuoja statistiškai reikšmingas ryšys tarp ligos kontrolès ir daromo klaidų skaičiaus inhaliuojant. Pacientai, kurie nepakankamai kontroliavo ligos simptomus, dare daugiau klaidų (mean 2,535, kai $\mathrm{p}<0,05$ ), nei pacientai kontroliuojantys ligos simptomus (mean 1,541, kai $\mathrm{p}<0,05$ ). Analizè buvo atkartota bei patikrinta su Mano Vitney kriterijumi.

Vertinant pacientų klaidų darymo skaičių prieš ir po paslaugos suteikimo gautas statistiškai reikšmingas klaidų skaičiaus sumažèjimas, prieš suteikiant paslaugą pacientai vidutiniškai darè daugiau klaidų (reiškia 
2,284, kai p<0,05) nei po paslaugos (reiškia 1,110, $\mathrm{p}<0,05$ ).

Tyrimo metu nustatyta, kad dažniausiai pasitaikanti klaida - pacientai neteisinga jèga ịkvepia vaistą. Ši klaida buvo dažniausiai aptikta Accuhaler, Aerolizer, Easyhaler bei Turbohaler inhaliatorių tipus vartojančių pacientų imtyse.

Ikvepimo stiprumo ittaka ligos kontrolei. İkvepimo stiprumui matuoti buvo naudojami In-check dial matuokliai. Vertinant įkvèpimo jëgą, buvo naudojami atskiros teisingo ¡kvèpimo ribos, skirtos dozuotam aerozoliniam preparatui (20-55 1/min) bei miletliniams inhaliatoriams (50-90 1/min.).

Buvo nustatyta, kad egzistuoja statistiškai reikšminga priklausomybè tarp ligos kontrolès ir teisingo vaisto ịkvèpimo $\left(\chi^{2}=4,329 ; \mathrm{p}<0.05\right)$.

Prieš vaistininkui suteikiant paslaugą teisingai ịkvejpdavo savo vaistus $23,36 \%$ tiriamosios imties pacientų. Po suteiktos paslaugos $25,82 \%(\mathrm{p}<0,05)$. Galima teigti, kad pacientams nepakanka vaistinejje atliktos treniruotès, todèl reikalinga nuolat tikrinti ịkvėpimo stiprumą su tam skirtais prietaisais.

\section{Diskusija}

Tam, kad būtų tinkamai ịvertinamas vaistininko teikiamos paslaugos efektas terapiniam gydymui, buvo matuojama astmos ligos kontrole prieš suteikiant paslaugą ir po antrojo vizito vaistineje. Šie duomenys buvo palyginti. Tiriamoje imtyje, prieš pradedant teikti paslaugą, buvo 26,20 proc. pacientų pakankamai arba visiškai kontroliuojančių astmos simptomus ir $73,80 \%$ proc. nepakankamai kontroliuojantys. Po pilno paslaugos ciklo kontroliuojančių ligos simptomus buvo 45,08 proc., o nekontroliuojančių buvo 54,92 proc. Reikia pažymėti, kad tarpiniai tyrimo rezultatai buvo paskelbti ir ligos kontrolès pokytis buvo stebetas tik ịvykdžius dali tyrimo [21].

Vertinant ligos pagerèjimą ar pablogèjimą pagal kontrolinę grupę, rezultatai rodo, kad 28,88 proc. anksčiau nekontroliavusių ligos simptomų pacientų po paslaugos suteikimo pradejo pakankamai kontroliuoti astmos simptomus (ACT $>20$ ), tačiau 6 pacientai, prieš paslaugos suteikimą pakankamai kontroliavę simptomus, perèjo į nekontroliuojančiu imtị, tikriausiai tai sąlygojo oro sąlygų ar gyvenimo būdo pokyčiai. Ankstesni kitų tyrejjų tyrimai parodè, kad paciento suvokimas apie inhaliacijų svarbą suteikia motyvaciją siekti teisingos inhaliatorių naudojimo technikos [22], todèl ligos kontrolès teigiamą pokytị galima aiškinti paciento edukacijos bei supratimo apie ligą ir jos gydymą kontekste. Tyrimų rezultatai rodo, kad vaistininkai gali prisidèti prie pacientų edukacijos, taip pagerinant ligos kontrolę bei gyvenimo kokybę [19].

Vertinant pacientų daromas inhaliavimo klaidas, lyginant I vizito ir II vizito vaistineje rezultatus, yra nustatytas statistiškai reikšmingas pokytis, kuris tiesiogiai koreliuoja su ligos kontrolès pagerèjimu. Prieš suteikiant paslaugą, tirtoje imtyje fiksuotas vidutinis klaidų skaičius yra lygus 2,284 klaidos, po paslaugos suteikimo fiksuotas 1,111 klaidų. Buvo konstatuota statistiškai reikšminga priklausomybè tarp ligos kontrolès pagerèjimo ir daromų inhaliavimo klaidų sumažejimo. Galima teigti, kad neteisingas paskirtų astmai gydyti vaistų inhaliavimas lemia nepakankamą ligos kontrolę. Tyrimo duomenimis, reikšminga edukuoti pacientus apie įkvèpimo stiprumą, kadangi pastebèta, jog pacientai nèra ịpratę skirtingai įkvèpti skirtinguose inhaliatorių tipuose esančius vaistinius preparatus, dèl to nepasiekiamas efektyvus terapinis vaistų veikimas. Svarstytina rekomendacija pacientams turèti asmeninius ịkvèpimo matuoklius, siekiant teisingo vaisto pernešimo iš prietaiso ị plaučius. Tyrimų rezultatai patvirtino mokslinių tyrimų duomenis, jog ị Sveikatos priežiūros stebèsenos grandinę integravus farmacijos specialistą, galima pasiekti teigiamus astmos kontrolès rezultatus [6-9].

\section{Išvada}

Tiriamosios grupès statistiškai reikšmingas ligos simptomų kontroliavimo didejjimas bei daromų inhaliavimo klaidų skaičiaus sumažejimas ịrodo, kad astma sergančių pacienty priežiūros grandinèje greta gydytojo ir slaugytojos integruojant farmacijos specialistą galima pasiekti racionalaus vaistu vartojimo bei geresnių ligos simptomų kontroliavimo.

\section{Literatūra}

1. Gauthier M, Ray A, Wenzel S. Evolving concepts of asthma. American Journal of Respiratory and Critical Care Medicine 2015; 192(6):660-8.

2. Health Minister of Lithuania, Hygiene Institute of Health Information Center. Health Statistics of Lithuania 2017. Internetine prieiga: http://www.hi.lt/uploads/pdf/leidiniai/Statistikos/ LT_sveik_stat_health/Lietuvos_sveikatos_statistika_2017_2. pdf [žiūrèta 2019-03-04].

3. Baddar S, Jayakrishnan B, Rawas O.A. Asthma control: importance of compliance and inhaler technique assessments. Journal of Asthma 2014; 51(4):429-34.

https://doi.org/10.3109/02770903.2013.871558

4. World Health Organisation. Global surveillance, prevention and control of chronic respiratory diseases: a comprehensive approach. Internetine prieiga: https://www.who.int/gard/publications/GARD\%20Book\%202 007.pdf [žiūrèta 2019-02-20].

5. Worth A, Hammersley V, Knibb R, Flokstra-de-Blok B, DunnGalvin A, Walker S. et al. Patient-reported outcome measures for asthma: a systematic review. NPJ Prim Care Respir Med. $2014 ; 24: 14020$.

https://doi.org/10.1038/npjpcrm.2014.20

6. Freehan M, Ranker L, Durante R, Cooper DK, Jones GJ, Young DC. et al. Adherence to controller asthma medications: 6-month 
prevalence across a US community pharmacy chain. Journal of Clinical Pharmacy and Therapeutics. 2015; 40(5):590-593. https://doi.org/10.1111/jcpt.12316

7. Saini B, LeMay K, Emmerton L, Krass I, Smith L, BosnicAnticevich S. et al. Asthma disease management - Australian pharmacists interventions improve patients asthma knowledge and this is sustained. Patient Education and Counseling 2011; 83(3):295-302.

https://doi.org/10.1016/j.pec.2011.05.001

8. Ogunbayo O, Schafheutle E, Cutts C, Noyce PR. A Qualitative study exploring community pharmacists' awareness of, and contribution to, self-care support in the management of longterm conditions in the United Kingdom. Research in Social and Administrative Pharmacy 2014;11(6):859-79.

https://doi.org/10.1016/j.sapharm.2014.12.010

9. Herborg H, Soendergaard B, Froekjaer B, Fonnesbaek L, Jorgensen T, Hepler CD. et al. Improving drug therapy for patients with asthma-part 1: patient outcomes. Am Pharm Assoc (Wash) 2001;41:539-50.

https://doi.org/10.1016/S1086-5802(16)31278-5

10. Carson KV, Chandratilleke MG, Picot J, Brinn MP, Esterman AJ, Smith BJ. Physical training for asthma. The Cochrane Library 2013; 30;(9):CD001116. https://doi.org/10.1002/14651858.CD001116.pub4

11. Global Initiative for Asthma. Global Strategy for Asthma Management and Prevention. Update 2018. Internetine prieiga: https:/ginasthma.org/wp-content/uploads/2018/04/wms-GINA-2018-report-V1.3-002.pdf [ žiūrèta 2019-03-04].

12. Stallberg B, Lisspers K, Hasselgren M, Janson C, Johansson G, Svardsudd K. Asthma control in primary care in Sweden: a comparison between 2001 and 2005. Prim Care Respir J. 2009; 18:279-86.

https://doi.org/10.4104/pcrj.2009.00024

13. Boulet LP, Vervloet D, Foster MJ. Adherence: the goal to control asthma. Elsevier 2012.3:148-69.

14. National Health Statistics Reports. Asthma prevalence health care use and mortality:united atates, 2005-2009. 2011. Internetine prieiga: https://www.cdc.gov/nchs/data/nhsr/nhsr032. pdf [Žiūrèta 2019-03-04].

15. Schulz M, Verheyen F, Muhlig S, Muller JM, Muhlbauer K, Knop-Schneickert E. et al. Pharmaceutical care services for asthma: a controlled intervention study. J Clin Pharmacol 2001;41:668-76.

https://doi.org/10.1177/00912700122010438

16. Directive 2011/24/Eu of the European Parliament and of the Council of 9 March 2011 on the application of patients' rights in cross-border healthcare. Article 3 - F. Internetinè prieiga: https://eur-lex.europa.eu/legal-content/EN/ TXT/?uri=CELEX\%3A32011L0024 [žiūrèta 2019-03-04].

17. Sakalauskas R., Danila R. ir kt. Lietuvos suaugusiųjų astmos diagnostikos ir gydymo sutarimas, 2015. Astmos diagnostikos ir gydymo rekomendacijos Kaunas, 2015. Internetinè prieiga: http://medicina.1smuni.1t/med/0503/0503-111.pdf [žiūrèta 2019-03-04].

18. Ministry of Health of The Republic of Lithuania. Hygiene Institute Health Information Center. Lithuanian Health and Health Care System 2017. Internetinė prieiga: http://www.hi.lt/ uploads/pdf/leidiniai/Statistikos/LT_sveik_stat_health/Lietuvos_sveikatos_statistika_2017_2.pdf [žiūrēta 2019-03-04].

19. Saini B, LeMay K, Emmerton L. et al. Asthma disease management-Australian pharmacists' interventions improve patients' asthmaknowledge and this is sustained. Patient Educ Couns 2011;83:295-302.

https://doi.org/10.1016/j.pec.2011.05.001

20. Haughney J, Price D, Barnes NC, Virchow JC, Roche N, Chrystyn $\mathrm{H}$. Choosing inhaler devices for people with asthma: current knowledge and outstanding research needs. Respiratory Medicine. 2010;104(9):1237-45.

https://doi.org/10.1016/j.rmed.2010.04.012

21.Nastaravicius A, Ramanauskiene K. Role of a community pharmacy service in care of bronchial asthma patients in Lithuania. Canadian Respiratory Journal 2018; 6060581. https://doi.org/10.1155/2018/6060581

22.Ovchinikova L, Smith L, and Bosnic-Anticevich S. Inhalertechnique maintenance: Gaining an understanding from the patient's perspective. J Asthma 2011;48:616-624.

https://doi.org/10.3109/02770903.2011.580032

\section{ANALYSIS OF THE NEED OF PHARMACIST SPECIALIZATED SERVICE FOR ASTHMA PATIENTS IN LITHUANIA}

A.Nastaravičius, K.Ramanauskienè

Key words: bonchial asthma, pharmacist consultation, review, inhalation technique.

Summary

The number of asthma patients increases continuously in Lithuania. Based on data from 2017 there were more than 121300 asthma patients and more than 46500 of them were adults.

The study objective was to assess whether the specialised consultation provided by the pharmacist regarding the prescribed asthma medicines could have any influence upon the patients' disease control.

Methods: the qualitative and quantitative study performed on the basis of grounded theory. The applied deduction method was based on the publications regarding the asthma management and the role of medicines. Kolmorgorov-Smirnov, and Chi-Square, Student T Paired samples criteria, Mann Whitney criterion as well as Spearman correlation coefficient were used for the statistical data evaluation.

Results: during the qualitative study it was established that pharmacy professionals have to provide the asthma patients with the information about the profile and action of used medicines, consequences of poor treatment compliance, peculiarities of inhalation technique, disease symptoms, the influence of non-controlled symptoms on patient's health, asthma control levels. It was established 
that 73.8 percent of 244 study subjects, who fully completed the service cycle, were not able to control the symptoms of their disease sufficiently before the study. The part of patients who were not able to control sufficiently the symptoms of their disease decreased to 54.92 percent after the intervention. The majority of inhalation mistakes were reported in the study subjects using Aerolizer and Aerosol inhaler inhalators. The lowest number of mistakes was reported in those using Easyhaler, Turbohaler as well as Accuhaler. After the provided consultation the mean number of mistakes decreased from 2.284 to 1.110 (when $\mathrm{p}<0.05$ ).

Conclusion: the statistically significant increase in the control of disease symptoms and decrease in the number of inhalation mistakes show that integration of pharmacy professional in the chain of asthma patients care together with the physician and the nurse can allow to achieve the rational use of medicines and better control of disease symptoms.

Correspondence to: arturas.nastaravicius@1smuni.lt

Gauta 2019-03-06 